\title{
Focusing Model: A Socialization Activities Group Learning of Intellectual Disability in The Classroom
}

\author{
Isna Ovari ${ }^{1}$, Yendrizal Jafri ${ }^{2}$ \\ isna.ovari@yahoo.com ${ }^{1}$, yendrizaljafri@ymail.com² \\ STIKes Perintis Padang
}

\begin{abstract}
Focusing Model: A Socialization Activities Group Learning of Intellectual Disability in The Classroom has been formed in the 1st year. The purpose of this secondyear study was to test the models in Bukittinggi State SLB for 24 respondents and SLB AR Payakumbuh for 16 respondents, then to improve the weaknesses of the models found during the trial, to create the right learning group model for mentally disabled students. The Focussing model consists of 5 activities, one of which is session socialization activities 1,2,3,4,5. The trial has been carried out from April to July 2018. Using the dependent t-test statistical test, the results of data analysis from Bukittinggi State SLB shows session socialization activities 1,2,3,4,5. Data analysis from SLB Bukittinggi showed that all session $\mathrm{p}=0,000$, however SLB Air Randah Payakumbuh showed that session socialization activities 2 verbal abilities p-value $=0.169$, session 3 verbal ability $p=0.968$, session 4 ability to convey topics, choosing topics and non verbal abilities $p=0.672,0.189$ and 0.265 . Next session 5 verbal skills asked and asked, answered and gave $\mathrm{p}=0.076$ and 0.135 . This means that there are no significant differences before and after the module is implemented in the class. The conclusion of session socialization activities $1,2,3,4,5$ carried out by mentally disabled students, proving that not all sessions provided significant differences before and after the module was implemented.
\end{abstract}

Keywords: Focusing Model, Model Testing, Socialization.

\section{Introduction}

Mentally disabled are children who have intellectual intelligence below the average accompanied by an inability to adapt, which arises during development or before the age of 18 , inability to adapt experienced in terms of communication, caring for oneself, adjusting to home life, social skills, utilization of public facilities, directing oneself, health, safety, academic functions, filling spare time and work. In developing countries, mental retardation becomes a big problem, It is estimated that the incidence rate is $0.3 \%$ of the entire population, $3 \%$ with intelligence under 70. Based on the intelligence score standard of the AAMR category (American Association of National Retardation), mental retardation in Indonesia ranks 10th in the world, when this is estimated to be around 6.6 million, (Data from the Directorate of Child Health Development, 2010) and Riskesdas, (2013) data showing that Indonesia's population with disabilities is $8.3 \%$ of the total population, of which $6.2 \%$ are children aged $15-24$ years and the population of mentally disabled children ranks the largest compared to the number of children with other limitations.

The three main characteristics of mentally disabled children are: first the general Intellectual function is significantly below the average, meaning that the deficiency is real so that the child 
in question requires special education services, for example, normal children have an average IQ 100, while the mentally ill IQ is the highest 70. Both experience a lack of behavioral adjustment (adaptive behavior), meaning that children who are mutually not /cannot do jobs that are appropriate to their age are only able to do the work done by children younger than them. The third is an intellectual disability takes place in the period of development, the meaning is that intellectual disability occurs during development, i.e. from conception to age 18 years.

The above is reinforced Somantri (2005) about mental retardation, namely the existence of backward intelligence, intelligence is a complex function that can be interpreted as the ability to learn information and adjust skills to problems - problems and situations - new life situations, learning from past experiences, thinking abstract, creative, can critically assess, avoid mistakes, overcome difficulties, and the ability to plan for the future [1].

The mentally retarded child has a disadvantage to it. Learning capacities, especially those of an abstract nature such as learning to count, write, and read are limited; their learning abilities tend to be without understanding or tend to learn by parroting. The existence of social limitations, mentally disabled children tend to be friends with children who are younger than their age, dependence on parents is very large, unable to assume social responsibility wisely, so they must always be guided and supervised. They are also easily influenced and tend to do things without thinking about the consequences. There are limitations of other mental functions, mentally disabled children need more time to carry out reactions to the situation they have just known, showing their best reaction when following routine things that they consistently experience day to day, unable to face any activities or tasks in for a long time, have limited language mastery. They do not experience articulation damage but the processing center (vocabulary that is not functioning properly). Therefore they need concrete words, and they are often heard. Besides, that differences and equations must be shown repeatedly. Simple exercises such as teaching big and small concepts, hard and weak, first, second, and last, need to use a concrete approach.

The difficulty of educators directs mentally disabled students to study, causing the learning prowess shown by students from day to day to be invisible, absent, let alone perform academically; this situation is aggravated by the system in the SLB namely: each student always goes up in class, no terms stay class. Some educators seem less eager when teaching their students in the class, undergoing routine teaching students in the class, sometimes feeling bored. Businesses that have been carried out by schools have not brought satisfactory results. So to help educators in SLB in teaching and maintaining student learning attention to last a long time, the way the teacher provides learning in class needs to be modified and developed but still consider the limitations of students, for example learning activities in the classroom are carried out in the form of groups with activities favored by students. The chosen activity is one that can develop fine motor skills, gross motoric, audio, visual, tactile, kinesthetic, interaction and student communication. Thus the urgency of this research is the creation of focussing models of mentally retarded students 'learning groups in class to focus students' learning attention, because the class learning model implemented so far has not shown group activities, in general, the teacher uses the individualization method, which means emphasizing the teacher's attention based on the individual differences of students. Students with intellectual disabilities learn according to their rhythms, but they also have to interact with friends or with their environment so that learning stays together in a class with different depth and breadth of material. Groupshaped learning is very suitable to be given to mentally retarded students, with the reason that each mentally impaired class consists of 4-5 students, this has fulfilled the requirements of a group. By what was conveyed by Rawlins, Williams, and Beck, (1993). That the number of comfortable group members is a small group whose members range from 5-10 people. If 
members are too many as a result, not all members have the opportunity to express their feelings and experiences, if the members are too few, lack of variety and interaction. Furthermore, the application of this study group focusing model can be combined with individualization learning methods. Although mentally disabled students experience intellectual barriers, they can still develop their potential provided they are given the opportunity to attend education with special service,s. Through this service, they will be able to carry out their duties so that self-confidence and self-esteem increase. An important component in guiding mentally disabled students is to increase self-esteem so that they do not withdraw / inferior and the community does not isolate them, because they are proven to be able to do something like other community members Research Objectives, this second year is to test the model, revise the model so that a perfect final model is formed, namely the focusing model of the mentally retarded student learning group in the class that is ready to be implemented in SLB [2].

\section{Methods}

This study uses Research and Development (R \& D), which is a research method used to produce a particular product or model and test the effectiveness of the product or model. The steps used in R \& D are (1) potential and problems, (2) collecting information (3) product design or models, (4) design validation, (5) design revisions, (6) product trials, (7) product revisions or model, (8) usage test, (9) product revision, (10) mass product, (Sugiyono, 2013). The subjects of this study were all elementary school students in grades 1-6, who were studying in class. SLB Negeri Bukittinggi, as many as 24 students and SLB Air Randah as many as 16 students. Supporting data that is considered important are information from the Principal, class teacher, students, observations of researchers, available infrastructure and several systems that apply in SLB. Model design trials have been carried out in two SLB namely Bukittinggi State SLB and SLB Air Randah located in Payakumbuh City. The basic consideration of the selection of research sites is because the two SLBs have long been established and the number of mentally disabled students is more than the other tuna students. Furthermore, the effectiveness of the model implemented in these two SLBs was evaluated. In accordance with the initial planning, in the second year of the study, the steps of $\mathrm{R}$ and $\mathrm{D}$ that have been carried out by researchers are steps to (6) model design trials, (7) model revisions after trials, (8) usage trials,(9) revision of the initial model, (10) the final model There are two types of data used in this study, qualitative data obtained through interviews with principals, teachers, students, literature studies and observations related to class module implementation. Quantitative data is obtained through the results of filling out the evaluation format before and after the module is implemented. Using a dependent-test statistical test.

\section{Results}

By the stages of research on proposals, in the second year researchers conducted a trial model on two SLB. The activity is to try out modules that have been compiled in the first year of research. The trial was started from May to the second week of August 2018. 
Table 1. Average Distribution of Socialization Activities, Sessions 1,2,3,4,5 Before and After Applied Modules in Bukittinggi State SLB.

\begin{tabular}{|c|c|c|c|c|c|c|}
\hline Variabel & \multirow{2}{*}{$\begin{array}{l}\text { Pre and Post Test } \\
\text { Assessment }\end{array}$} & \multirow{2}{*}{ Mean } & \multirow{2}{*}{ SD } & \multirow{2}{*}{ SE } & \multirow{2}{*}{$\begin{array}{c}\mathrm{P} \\
\text { value }\end{array}$} & \multirow{2}{*}{$\mathrm{N}$} \\
\hline Dissemination & & & & & & \\
\hline \multirow[t]{2}{*}{ Session 1: Verbal } & Before the module & 6.25 & 2.192 & 0.447 & 0.000 & 24 \\
\hline & After the module & 12.50 & 4.384 & 0.895 & & \\
\hline \multirow[t]{2}{*}{ Session 1: Non-Verbal } & Before the module & 6.25 & 2.575 & 0.526 & 0.000 & \\
\hline & After the module & 12.25 & 5.318 & 1.086 & & \\
\hline \multirow[t]{2}{*}{ Session 2: Verbal } & Before the module & 11.17 & & 1.268 & 0.000 & \\
\hline & After the module & 22.17 & 6.211 & 2.536 & & \\
\hline \multirow[t]{3}{*}{ Session 2: Non-Verbal } & Before the module & 6.00 & 12.42 & 0.631 & 0.000 & \\
\hline & After the module & 12.33 & 3.093 & 1.153 & & \\
\hline & & & 5.647 & & & \\
\hline \multirow[t]{2}{*}{ Session 3: Verbal ask } & Before the module & 5.00 & 3.587 & 0.732 & 0.000 & \\
\hline & After the module & 10.33 & 7.175 & 1.465 & & \\
\hline \multirow[t]{2}{*}{ Session 3: Verbal said } & Before the module & 5.50 & 3.401 & 0.694 & 0.000 & \\
\hline & After the module & 10.83 & 6.926 & 1.414 & & \\
\hline \multirow[t]{2}{*}{ Session 3: Non-Verbal } & Before the module & 5.75 & 3.352 & 0.684 & 0.000 & \\
\hline & After the module & 1.50 & 6.705 & 1.369 & & \\
\hline \multirow{3}{*}{$\begin{array}{l}\text { Session 4: To convey the } \\
\text { message to the } \\
\text { topic }\end{array}$} & Before the module & & 3.226 & 0.658 & 0.000 & \\
\hline & After the module & 2.83 & 6.452 & 1.317 & & \\
\hline & Before the module & & 3.049 & 0.622 & 0.000 & \\
\hline \multirow[t]{2}{*}{ Session 4: Choose a topic } & After the module & 5.67 & 6.098 & 1.245 & & \\
\hline & Before the module & 2.42 & 3.049 & 0.622 & 0.000 & \\
\hline \multirow[t]{3}{*}{ Session 4: Non-Verbal } & After the module & 4.83 & 6.204 & 1.266 & & \\
\hline & & 2.42 & & & & \\
\hline & & 4.67 & & & & \\
\hline \multirow[t]{2}{*}{ Session 5: Ask and ask } & Before the module & 3.00 & 3.388 & 0.692 & 0.000 & \\
\hline & After the module & 6.00 & 6.776 & 1.383 & & \\
\hline \multirow{2}{*}{$\begin{array}{c}\text { Session 5: Responsibility } \\
\text { and give }\end{array}$} & Before the module & 2.00 & 2.449 & 0.500 & 0.000 & \\
\hline & After the module & 3.75 & 4.618 & 0.943 & & \\
\hline \multirow[t]{2}{*}{ Session 5: Non-Verbal } & Before the module & 6.00 & 3.176 & 0.648 & 0.000 & \\
\hline & After the module & 11.83 & 6.295 & 1.295 & & \\
\hline
\end{tabular}

Table 1 shows that: Session 1 socialization activities of verbal and non-verbal abilities showed there were significant differences before and after the module was applied, the value of $\mathrm{p}=$ 0.000. Session 2 socialization activities verbal and non-verbal abilities showed there were significant differences before and after the module was applied, the value of $p=0.000$. Session 3 socialization activities verbal ability: asking questions, answering and non- verbal abilities showed there were significant differences before and after the module was applied, the value of $p=0.000$. Session 4 socialization activities verbal ability: conveying topics, choosing topics and non-verbal abilities showed there were significant differences before and after the module was applied, each value $\mathrm{p}=0.000$. Session 5 socialization activities verbal ability: asking and asking, answering and giving and nonverbal abilities showed there were significant differences before and after the module was applied, each value $\mathrm{p}=0.000$. 
Table 2. Average Distribution of Dissemination Activities, Session 1, 2,3,4,5 Before and After Applied Modules at SLB Air Randah Payakumbuh.

\begin{tabular}{|c|c|c|c|c|c|c|}
\hline Variabel & \multirow{2}{*}{$\begin{array}{l}\text { Pre and Post } \\
\text { Test Assessment }\end{array}$} & \multirow{2}{*}{ Mean } & \multirow{2}{*}{ SD } & \multirow{2}{*}{ SE } & \multirow{2}{*}{$\begin{array}{l}\mathrm{P} \\
\text { value }\end{array}$} & \multirow{2}{*}{$\mathrm{N}$} \\
\hline Dissemination & & & & & & \\
\hline \multirow{2}{*}{ Session 1: Verbal } & Before the & 5.75 & 3.568 & 0.892 & 0.000 & 16 \\
\hline & module & 10.81 & 4.086 & 1.022 & & \\
\hline \multirow[t]{3}{*}{ Session 1: Non-Verbal } & After the module & 6.00 & 3.578 & 0.894 & 0.000 & \\
\hline & $\begin{array}{l}\text { Before the } \\
\text { module }\end{array}$ & 12.69 & 3.240 & 0.810 & & \\
\hline & After the module & & & & & \\
\hline \multirow[t]{2}{*}{ Session 2 : Verbal } & Before the & 1.50 & & 1.746 & 0.169 & \\
\hline & module & 15.06 & 6.986 & 2.580 & & \\
\hline \multirow[t]{4}{*}{ Session 2 : Non-Verbal } & After the module & 6.50 & & 0.806 & 0.000 & \\
\hline & Before the & 12.31 & 10.31 & 0.943 & & \\
\hline & module & & 3.225 & & & \\
\hline & After the module & & 5.772 & & & \\
\hline \multirow{3}{*}{$\begin{array}{l}\text { Session } \quad 3: \quad \text { Verbal } \\
\text { ask }\end{array}$} & Before the & 5.50 & 3.830 & 0.957 & 0.968 & \\
\hline & module & 5.56 & 5.125 & 1.281 & & \\
\hline & After the module & 5.50 & 3.830 & 0.957 & 0.000 & \\
\hline \multirow[t]{2}{*}{ Session 3: Verbal said } & Before the & 7.12 & 5.795 & 1.449 & & \\
\hline & module & 4.50 & 4.099 & 1.025 & 0.000 & \\
\hline \multirow[t]{3}{*}{ Session 3 : Non-Verbal } & After the module & 9.44 & 6.261 & 1.565 & & \\
\hline & $\begin{array}{l}\text { Before the } \\
\text { module }\end{array}$ & & & & & \\
\hline & After the module & & & & & \\
\hline \multirow{2}{*}{$\begin{array}{l}\text { Session } 4: \text { To convey the } \\
\text { message to the topic }\end{array}$} & Before the & 2.25 & 3.256 & 0.814 & 0.672 & \\
\hline & module & 5.88 & 3.931 & 0.983 & & \\
\hline \multirow[t]{2}{*}{ Session 4 : Choose a topic } & After the module & 1.62 & 2.825 & 0.706 & 0.189 & \\
\hline & Before the & 3.44 & 3.633 & 0.908 & & \\
\hline \multirow[t]{4}{*}{ Session 4 : Non-Verbal } & module & 1.50 & 2.875 & 0.719 & 0.265 & \\
\hline & After the module & 3.00 & 4.179 & 1.045 & & \\
\hline & $\begin{array}{l}\text { Before the } \\
\text { module }\end{array}$ & & & & & \\
\hline & After the module & & & & & \\
\hline \multirow[t]{2}{*}{ Session 5 : Ask and ask } & Before the & 2.50 & 3.540 & 0.885 & 0.076 & \\
\hline & module & 5.81 & 5.879 & 1.470 & & \\
\hline \multirow{6}{*}{$\begin{array}{l}\text { Session } 5: \text { Responsibility } \\
\text { and give } \\
\text { Session } 5: \text { Non-Verbal }\end{array}$} & After the module & 1.50 & 2.449 & 0.612 & 0.135 & \\
\hline & Before the & 3.81 & 4.750 & 1.188 & & \\
\hline & module & 4.50 & 4.019 & 1.025 & 0.000 & \\
\hline & After the module & 11.31 & 5.896 & 1.474 & & \\
\hline & Before the & & & & & \\
\hline & After the module & & & & & \\
\hline
\end{tabular}

Table 2 shows that the socialization session 1 of verbal and non- verbal abilities showed that there were significant differences before and after the module was applied, the value of $\mathrm{p}=$ 0.000 . Session 2 socialization activities verbal ability showed no significant differences before and after the module was applied, $\mathrm{p}=0.169$. However, non-verbal ability shows that there are 
significant differences before and after the module is applied, the value of $p=0.000$. Session 3 socialization activities verbal ability: asking indicates there is no significant difference before and after the module is applied, the value of $p=0.968$. However, verbal ability to answer and non-verbal abilities there are significant differences before and after the module is applied, the value of $\mathrm{p}=0.000$. Session 4 socialization activities verbal ability: conveying topics, choosing topics and non -verbal abilities showed no significant differences before and after the module was applied, the values $\mathrm{p}=0.672,0.189$ and 0.265 . Session 5 socialization activities verbal ability: asking and asking, answering and giving shows there are no significant differences before and after the module is applied with the values $p=0.076$ and 0.135 . However, non-verbal ability shows that there are significant differences before and after the module is applied, the value of $\mathrm{p}=0.000$.

The results of the trial proved that there were significant differences before the module was applied to the students after the module was applied to students. Whereas initially students in doing the assignments given by the teacher are done as they like, the assignments can sometimes be finished, but often not finished because students are lazy and bored quickly, students' eye contact with teachers or friends in the class cannot last long. However, after applying the student's eye contact module with the teacher and friends in the class can last longer, students can complete the given task (visible results), for example coloring the picture to completion, following the activities from beginning to end, starting with simple communication. Among them with a cheerful atmosphere because the activities that are implemented in the module are activities that are fun for students including socialization, games, sports, arts, and skills. This situation affects the attention span of students when attending classes in class. Their anxiety is reduced and calmer until the teacher closes the lesson. The results of the model trial provide 2 pieces of data, namely qualitatively and quantitatively. Qualitatively, based on the results of the model trials, input from the teachers in the SLB and observations of the researcher, that there are several weaknesses encountered when the contents of the module are implemented in the class, including those from SLB Negeri Bukittinggi, Not all activities in the module can be applied for SLB students. The modules should be grouped into two, namely modules for lowclass groups including classes 1,2, and 3 and modules for high-class groups covering classes 4,5 and 6. Because some activities cannot be carried out at all in the low class, such as students' abilities to discuss a topic with friends in a group, maintain eye contact while communicating with friends or teachers. While on the other hand some activities are very easy to do by highclass students so they don't get obstacles in implementing them. SLB Air Randah Payakumbuh Students who were in one class turned out to also have experienced physical impairment, such as weakness in the hands and feet, so they needed a wheelchair, mute, Mongolia, so some activities could not be done at all even though they were guided repeatedly. Besides, there are only 2 class members. The safety results of the researcher have not all the teachers in order to carry out activities according to procedural, the sequences are not sequential.

\section{Discussion}

After several weaknesses in the model were identified, the researcher immediately made improvements and modifications, especially the contents of the module with the right types of activities for both low class and high class. The improvements made were: arranging activities in the model into 2 groups, as seen in the table of the focusing model of the mentally disabled students' learning groups in the class, the results of the revisions. 


\section{Conclusions}

Researchers have implemented all activities that have been modulated to mentally disabled students from grade 1 to class 6 . Assessment is done twice, the time before the module is implemented, where the researcher first evaluates using the format provided. Next, the researcher gives guidance to students twice. After those students are again assessed using the same format. The result is that there are differences in mean values before the module is implemented after the module is implemented for students. The statistical test obtained $p=0,000$ concluded that there were significant differences in the average between socialization activities before and after the module was applied.

Based on the results of the trial, several improvements have been made by the researcher, namely: revising the model and contents of the module. Teachers in SLB always explore their abilities in finding new learning models that match the limitations experienced by their students, so students do not get bored quickly. Mentally disabled students will show perseverance and good empathy if they get service, treatment and a conducive environment. Thus, it is expected that students' attention in class can change for the better. Besides, the activities favored by students need to be facilitated with sufficient teaching aids, so that they can practice over and over again because, with regular practice, proud achievements can be achieved.

\section{References}

[1] Ciptono, Supriyanto: Establish Self-Sufficient Children. Scientific Work was delivered at the BP Diksus Special Advisory Teacher Training in Central Java Province. (2010).

[2] AAMR The American Association of National Retardation (AAMD): Classification in Mental Retardation. https: //law.resource.org

[3] Basic Health Research (Riskesdas). Ministry of Health of the Republic of Indonesia. (2013)

[4] Sumantri: Development of Motoric Skills for Early Childhood. Classroom action research. Aditya Medika. Yogyakarta (2005).

[5] Rawlins, Williams, Beck: Mental Health Psychiatric Nursinag: A Holistic Life-Cycle Approach; Mosby-Year Book. (1993) 